
TO ROMAN LAW. 7 HE Roman law of guardianship grew out of the family organinheritance. The power of a guardian is that form of family power which ordinarily takes the place of paternal power when there is no one to exercise the latter. It was originally at Rome but an extension of the paternal power. ${ }^{1}$ In this respect the conception of guardianship is different in English law,-English guardianship rests on the principle of protecting the bodily and mental immaturity of youth. ${ }^{2}$

Duties common to all guardians (tutors or curators). I. Every guardian, whether tutor or curator, must give security for the faithful performance of his duties. This is also the rule in Anglo-American law. ${ }^{3}$

2. He must make an inventory of the property of his ward. The French, Japanese, and Anglo-American law are the same as the Roman. ${ }^{4}$

3. He was personally liable at Roman law for fraud, neglect, or waste of the ward's property. And he could also be removed for such malfeasance in office; this was known as removal on the charge of suspicion (crimen suspecti). If he wasted or alienated the ward's property in any way, not only may he be removed, but he was also liable to a double value fine, or to a restitution to the ward upon the ward's reaching majority or upon his own removal.

In German law it is provided that the guardian cannot dispose of or give away the property of the ward. Almost all his acts of an obligatory nature must receive the sanction of the family council. ${ }^{5}$ In French law the guardian cannot contract an obligation or sell property for the ward without consent of the family council. ${ }^{\circ}$ In England and America, alienation of the ward's property cannot be had without sanction of the proper court.

4. The guardian-tutor or curator-has charge of the person as well as the property of the ward. ${ }^{7}$ This is also the rule of French, Spanish, German and Anglo-American law. ${ }^{8}$

\footnotetext{
1 See Maine, Ancient Law, ch. 5; Williams, Inst. of Justinian, p. 3 I.

2 Maine, Ancient Law, ch. 5 .

3 Williams, Inst. of Justinian, p. 37, 42.

- Civil Code of France, 470; Japan 917.

5 Civil Code of Germany, I804, 1812.

- Civil Code of France, 450, 457.

7 Inst. of Justinian, I, 14, 3; Sohm, Inst. of Rom. Law (Ledlie 3 d ed.) $\S$ I03, p. 488.

$s$ Civil Code of France, 450; Spain; Germany 1794; England and United Statessee Terry, Common Law, p. 690; Williams, Inst. of Just., p. 32.
} 
5. The guardian - tutor or curator-must hand in a final account of his administration to the ward or his heirs upon the termination - of his guardianship.

Modern law repeats the Roman on this point. The French civil code provides" that "Every guardian is accountable for his management when it has expired," and that "every guardian, other than the father and the mother, may be compelled, even during the guardianship to give . . . statements of the situation of his management . . . but not more than one in each year." The Japanese Law is the same as the Roman. ${ }^{10}$ German, Spanish and AngloAmerican law require, like the Roman, a final account to the ward.11

State control over guardianships generally. Although not so pronounced as in modern law, such control was present in Roman law. The State required the guardian to give security against maladministration. It punished him for failure to make an inventory. By the Emperor Severus in the year I95 was introduced the rule that no alienation of the ward's property could take place without the sanction of the State. In some cases the State might perform the duty of removing a guardian.

The two kinds of Guardianship. There were two kinds of guardianship in Roman law,-tutorship (tutela) and curatorship (curatela). These terms are used according to the guardian's authority, or, conversely, the relative incapacity of the ward. The ward was known in Roman law as a pupillus (pupil). The guardian was called in Roman law either tutor or curator.

\section{TUTORSHIP (tutela).}

That form of guardianship known in Roman law as tutela was concerned with two classes of persons,-persons under puberty and women.

A. The guardianship of persons under puberty (tutela impuber$u m$ ). Such persons are often called minors. But minor means here a person sui juris, independent of the paternal power but under the age of puberty. Puberty was fixed in the Justinian law at fourteen for males and twelve for females. Such a person must have a guardian, known as tutor.

Who may be a guardian (tutor). To be a guardian, a person must be twenty-five years of age, a citizen and not an alien. No woman could be such, save the mother or grandmother of the ward.

\footnotetext{
Arts. 469 and 470.

${ }^{10}$ Civil Code of Japan, 937.

2 Civil Code of Germany, IS02, I840; Spain, 279 et seq.; Robinson, El. Law, § 200.
} 
In Anglo-American law no person under majority can act as a. guardian,-a rule based on the Roman rule of making eligibility depend upon attaining the age of unlimited capacity. ${ }^{12}$

The tutorship (tutela) a public office; excuses relieving therefrom. The Roman law treated the duty of guardianship as a public burden (munus publicum). No one could refuse to act as a guardian unless relieved by certain legal excuses.

Some of these excuses in Roman law were: I. Having three living children at Rome, or four in Italy', or five in the provinces,children dying in military service for the state were counted as if alive. The Spanish is like the Roman law,-having five children is an excuse. ${ }^{13}$

2. Three burdens of guardianship at one time. In Spanish law one burden of guardianship on hand is an excuse from taking up a second. ${ }^{1+}$

3. Having certain functions or duties requiring absence from home on business for the state. This is also an excuse in Spanish law, ${ }^{15}$ but not in English law. ${ }^{16}$

4. Poverty. This is also an excuse in Spanish law, ${ }^{17}$ and probably in English law. ${ }^{18}$

5. Ill-health. This is also an excuse in Spanish law. ${ }^{19}$

6. Illiteracy. This is also an excuse in Spanish law. ${ }^{20}$

7. Being over 70 years of age. The Spanish law reduces the limit to 60 years,-over 60 is an excuse. ${ }^{21}$

The classes of guardians (tutors). From the mode of their appointment guardians-tutors-were of four classes: testamentary guardians, statutory guardians, guardians appointed by courts, fiduciary guardians.

I. Testamentary guardians (tutores testamentarii). These are appointed by the father's will. To make the appointment valid the ward must be alieni juris until the father's death and become sui juris only by such death.

The English Common law allows as to minor children testamentary guardians, which however differ in some details from the Roman

12 Williams, Inst. of Justinian, p. $4^{2}$.

${ }^{13}$ Civil Code of Spain, art. 244 .

14 Ibid.

${ }^{15}$ Civil Code of Spain, 244.

${ }^{10}$ Williams, Inst. of Justinian, p. 42.

${ }^{17}$ Civil Code of Spain, 244.

is Williams, Inst. of Justinian, p. 46, 43 .

${ }^{19}$ Civil Code of Spain, 244 .

20 Ibid.

${ }^{2}$ Ibid. 
law testamentary guardians. ${ }^{22}$ In certain cases, too, in the modern law of England a mother may appoint a guardian by will. ${ }^{23}$ In England and America, by force of statute a father (and in most places a mother if the father is dead) may appoint a guardian for a child by deed or will, which guardianship may be made to last until the child comes of age or for a shorter time. Such guardians are called, rather loosely, guardians by statute, but more properly, inasmuch as they are appointed by will, testamentary guardians..4

2. Statutory guardians (tutores legitimi). These are so called because appointed by operation of law when there was no testamentary appointment. By the Law of the XII Tables this appointment fell on the agnates, and, failing them, the cognates gentilice. In Justinian Roman law it fell on the nearest capable ascendant heir.

In French law, the guardianship of ascendants goes to the nearest ascendant, the paternal relative being preferred to the maternal relative. ${ }^{25}$ The only partial counterpart in English law to the statutory agnatic guardianship of the Roman law is the ancient English law guardianship by nature and guardianship by socage,--both of which may have been suggested by the Roman law statutory guardianship of agnates. ${ }^{26}$

3. Guardians appointed by the courts (tutores dativi). ${ }^{2 \pi}$ In default of testamentary or statutory guardians, the proper Roman magistrate-praetor, governor of a province, etc.-appointed guardians either temporarily or to fill a vacancy.

In Spanish law this class of guardians is found they are appointed by the municipal judge on request of a family council held before him. ${ }^{28}$ In Anglo-American law the guardian ad litem as well as the vast body of guardians of minors are judicially appointed guardians. The long standing jurisdiction of the English Court of Equity over infants-often delegated in the United States to a surrogate court or court of probate-is probably borrowed from the Roman praetor's jurisdiction over the same class of persons. ${ }^{29}$

4. Fiduciary guardians (tutores fiduciarii). Fathers had to act as guardians for their emancipated sons not of full age, and masters for their manumitted slaves. This is often called in the classic

$=$ Williams, Inst. of Justinian, p. 32 ; Terry, Common law, p. 690 .

23 Williams, Inst. of Justinian, p. 33, 49 \& 50 Vict. c. 27.

34 Terry, Common law, p. 690.

25 Civil Code of France, 402-405.

s Williams, Inst. of Justinian, p. 34; Stephen, Commentaries, vol. II, bk. III, ch. IV.

$x$ Gaius and Ulpian call testamentary guardians by this name (Gaius I, 154), but in the law"of Justinian it is used only to designate guardians appointed by magistrates.

as Civil Code of Spain, 23I-232.

20 Williams, Inst. of Justinian, p. 36 . 
Roman law ${ }^{30}$ fiduciary guardianship, and the guardian, fiduciary tutor. In Justinian's time, the words "fiduciarius tutor" acquired a different meaning, - the children formerly in power of a deceased parent who in his lifetime emancipated a child: these children formerly in power become fiduciary guardians over their sons, brothers and sisters and the rest.

There is a survival of the Roman fiduciary guardianship of parents in Anglo-American and other modern law where the father or mother has a very limited amount of control over children set free or given their time. ${ }^{31}$

Powers and duties of guardians (tutors). These were determinable when the degree of incapacity of the pupillus is established,the younger the ward the greater the authority of the tutor.

I. If the ward is under seven years of age (infans), the tutor acts in his own name for the ward. The pupillus cannot perform by himself, even with the tutor's consent, any legal act. The custody of the infans went to his mother.

2. After the ward is seven years old ( $p u p i l l u s$ ) he has intellectus but not judgment. The tutor acts with him, adds his authority expressily or by ratification to the act of the pupillus, which makes it a juridical act binding both the ward and the person with whom he deals.

The English infant as well as ward corresponds to the Roman pupillus, provided it be borne in mind that English law has generally amalgamated the two ages of capacity and recognizes but one, except as to marriage and criminal responsibility.

As to his contracts the ward in Roman law binds himself, in any event, only so far as a transaction benefits himself: the ward can never make his condition worse. In English law the rule is practically like the Roman. By English law all contracts by infants made to his prejudice or disadvantage are void,-all others are voidable at his election. ${ }^{82}$

B. The guardianship of women (tutela mulierum). This guardianship was anciently declared "perpetual." The Roman jurist Gaius during the early Empire states ${ }^{33}$ that "Whatever their age and notwithstanding their marriage, if they were females, according to our ancestors, even women who have reached their majority, on account of their levity of disposition, require to be kept in tutela." This

\footnotetext{
A $D$.

${ }^{30}$ For instance, in the time of the Roman jurist Gaius,-latter half of and century,

${ }^{31}$ Williams, Inst. of Justinian, pp. 35,36 .

sabid., pp. 3I, 38; 2 Stephen, Comm., bk. III, ch. IV.

33 Gaius, Institutes, I, § 144 .
} 
tutela was either of her agnates or her husband. But this had become attenuated from the end of the Roman Republic itself,-a woman under guardianship at the beginning of the Empire can generally dispose of her property. And Gaius himself records how a woman's guardian may be forced to give his authority to her acts; and the Roman jurist Ulpian records that the Emperor Claudius ${ }^{34}$ abolished the statutory guardianship of agnates over women. In the early imperial Roman law there was always another sure way of escaping the tutela: if a freeborn woman had three, or a freed woman four, children, legitimate or illegitimate.

Traces of the "perpetual" guardianship of women are found in a very shadowy attenuated form as late as the reign of Diocletian. ${ }^{35}$ In the year 4Io-a little over a century prior to Justinian's era-the guardianship of women absolutely disappeared in consequence of a statute of the Emperors Honorius and Theodosius. It is not found at all in the Justinianean Roman law, nor does it exist in modern law.

\section{Curatorship (curatela).}

It was gradually recognized in Roman law that persons between fourteen and twenty-five need some protection. An individual of fourteen is fully sui juriș, but needs counsel and help to prudently manage his affairs. A minor under twenty-five who was defrauded could, by the lex Plaetoria, bring a criminal prosecution against the person injuring him. The praetor would grant him a restitutio in integrum if the transaction injured the minor. Therefore a person would hesitate to deal with a minor under twenty-five, because he might avoid a transaction. The Emperor Marcus Aurelius enacted that a plea of minority would not be received by the courts if a curator were appointed for a minor on his application. This is the basis of the Roman law as to curators.

Curators are special or general. No person under twenty-five could be forced to receive a curator against his will, unless insane, or engaged in a lawsuit, br unless a debtor wished to compel him to receive payment. Curators in Roman law were general-appointed over the entire estate of the person in curatorship, or special一appointed for a certain affair or transaction.

In modern law curators are either general or special, as in Roman law. The guardian ad litem, although not called usually a "curator," is an excellent illustration of the special guardian in English lawa survival of the Roman special curator.

Reigned 4I-54 A. D.

is $284-305$ A. D. 
To be eligible for appointment as' a curator, a person in Roman law must be twenty-five years old completed. This rule was also applied to eligibility for appointment as tutor,-twenty-five being the age where full civil capacity could be obtained by a person sui juris. In modern law, the person appointed as guardian must have attained the full capacity given by majority.

Powers and duties of curators. The curator was not so powerful as the tutor, for the person under curatorship, unless insane or mentally incapacitated, could legally act without his consent, subject to restitution by the praetor if damaged in so doing. Generally however, as a matter of precaution, the consent of the curator was obtained.

The curatorship of insane persons, spendthrifts, and other naturally incapable persons. This curatorship owes its origin to the ancient Roman Law of the XII Tables. At first the agnates were such curators. In Justinianean Roman law these curators were appointed judicially, i.e., by the magistrates. Ordinarily the nearest ascendant was appointed.

Survival of the guardianship of insane and incapable persons in modern laze. This survival is world-wide. These unfortunate persons even when over the age of majority are protected by guardians, called generally "curators" in so-called Latin countries. And the Roman law protection of the deaf and dumb by guardianship is frequently to be found in modern law.

The German civil code provides" "That any person. who is totally incapable by reason of mental infirmities of managing his affairs should be put under guardianship." By article I899 the father of such incapable should be appointed; if not alive, the mother.

In French law "The adult who is in an habitual state of imbecility, dementia or madness, should be interdicted, even when this state presents lucid intervals . . The interdiction or the appointment of an adviser shall take effect from the day of the judgment. All acts subsequently done by the interdicted, or without the assistance of the adviser, shall be null. A deaf and dumb person who cannot write must have a curator appointed to validly accept a gift.",'

Spanish law similarly provides, like the Roman, for the guardianship of the insane, weak-minded, spendthrifts and deaf and dumb persons. $^{38}$

By the Japanese civil code "A case for guardianship arises when.

so Art. 1896 .

az Civil code of France, 489, 502, 936.

${ }^{25}$ Civil code of Spain, 213, 220-221.

39 Civil code of Japan, 900, 9rr, 9rz. 
a person of full age has been adjudged incompetent. . . Wéakminded, deaf, dumb or blind persons and spendthrifts may be placed under curatorship as quasi-incompetent. . . . A quasi-incompetent person must have the consent of his curator for contracting any obligation, bringing or defending a suit, and accepting or refusing an inheritance." 39

In England at common law the King as parens patriae is the guardian of all idiots and lunatics, which function he exercises through some Court, e. g., Chancery. In the United States the State takes the place of the King and acts through the courts of equity or of probate. If the insane person has property, a judicial inquiry into his sanity results in a guardian (or, to use the other names, "conservator," "committee") being appointed to take charge of his property and often his person. ${ }^{40}$ In regard to spendthrifts (prodigi) the law of Scotland is the same as the Roman law; but English law does not take jurisdiction over such persons unless practically aberration of mind exists. ${ }^{41}$ In most places a "guardian" (or "conservator," or "committee") may be appointed for the property of a person, who is a spendthrift and squanders his property. ${ }^{42}$ Persons who are deaf and dumb are not ipso facto protected by guardianship in English law, as in Roman law.

Curatorship is combined with tutorship in modern law. As to sane and capable persons the jurisprudence of modern civilized countries has combined the minority of the curatorship with that of the tutorship-thus uniting minority and wardship, which are generally terminated by the ward reaching majority. In Scotch law the terms "tutor," "curator," and "pupil" are still technical terms used largely as in Roman law."

Blackstone recognizes that the English guardian fills the offices of both tutor and curator. ${ }^{44}$ The term "curator" has survived in the law of England for a special use.45 In "England it is not uncommon for the full enjoyment of property to be to be postponed in a will or settlement until the person entitled attains the age of twenty-five." 40 This is curiously reminiscent of the Roman rule that at twenty-five, 'all guardianship-the curatorship-ceases.

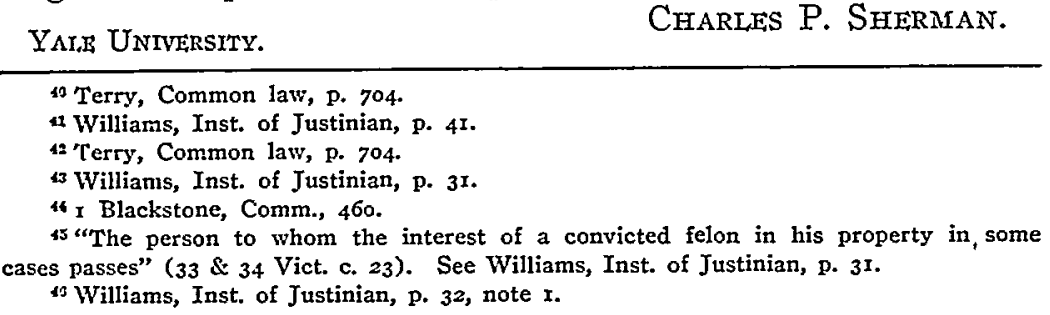

